\title{
Pengaruh Intellectual Capital terhadap Kinerja Keuangan (Financial Performance) (Studi Empiris Pada Perusahaan Publik Di Bursa Efek Indonesia)
}

\author{
INOVA FITRI SIREGAR \\ Dosen Tetap Fakultas Ekonomi Universitas Lancang Kuning \\ Jln. Yos Sudarso KM 8 Rumbai \\ E-mail : siregar_inovafitri@yahoo.com
}

\begin{abstract}
This study aims to examine the influence of Intellectual Capital on Financial Performance and Market Value of the company that will be seen from 4 (four) sectors of companies listed in Indonesia Stock Exchange. The data used in this study are 87 service and property companies and 154 manufacturing and trading companies obtained from the Indonesia Stock Exchange between 2007 to 2009. Data analysis methods used consist of Descriptive Statistics, Classical Assumption Testing, Multiple Regression Analysis, and Test Analysis of Variance to determine the influence of Intellectual Capital in the formation of Financial Performance and Market Value. The results of this study indicate that simultaneously (together) components of Intellectual Capital Efficiency have a positive effect on the formation of Financial Performance and Market Value. In the service, property, manufacturing and trading companies, there are different intellectual capital performances for each service industry sector, property, manufacturing and trading. But partially researchers found that not all components of the forming of Intellectual Capital Efficiency affect the formation of Financial Performance and Market Value Company. The most dominant found by researchers is the influence of Structural Capital Efficiency.
\end{abstract}

Keywords: intellectual capital, Financial Performance

Perkembangan dalam bidang ekonomi membawa dampak perubahan yang cukup signifikan terhadap pengelolaan suatu bisnis dan penentuan strategi bersaing. Para pelaku bisnis mulai menyadari bahwa kemampuan bersaing tidak hanya terletak pada kepemilikan aktiva berwujud, tetapi lebih pada inovasi, sistem informasi, pengelolaan organisasi dan sumber daya manusia yang dimilikinya. Oleh karena itu, organisasi bisnis semakin menitikberatkan akan pentingnya knowledge asset (aset pengetahuan) sebagai salah satu bentuk aset tak berwujud .

Peranan IC (Intellectual Capital) semakin strategis, bahkan akhir-akhir ini memiliki peran kunci dalam upaya melakukan lompatan peningkatan nilai di berbagai perusahaan. Hal ini disebabkan adanya kesadaran bahwa IC (Intellectual Capital) merupakan landasan bagi perusahaan untuk unggul dan bertumbuh. Kesadaran ini antara lain ditandai dengan semakin seringnya istilah knowledge based company muncul dalam wacana bisnis. Istilah tersebut ditujukan terhadap perusahaan yang lebih mengandalkan pengelolaan IC (Intellectual Capital) sebagai sumber daya dan longterm growth-nya. Knowledge based company adalah perusahaan yang diisi oleh komunitas yang memiliki pengetahuan, keahlian, dan keterampilan. Ciri lainnya adalah perusahaan ini lebih mengandalkan pengetahuan dalam mempertajam daya saingnya, yaitu dengan lebih berinvestasi di bidang IC (Intellectual Capital). Sebagai akibatnya, nilai dari knowledge based company utamanya ditentukan oleh IC (Intellectual Capital) yang dimiliki dan dikelolanya.

Munculnya "new economy", yang
secara prinsip didorong oleh perkembangan teknologi informasi dan ilmu pengetahuan, juga telah memicu tumbuhnya minat dalam intellectual 
capital (Petty dan Guthrie, 2000; Bontis, 2001). Salah satu area yang menarik perhatian baik akademisi maupun praktisi adalah yang terkait dengan kegunaan IC sebagai salah satu instrument untuk menentukan nilai perusahaan (Edvinsson dan Malone, 1997; Sveiby, 2001). Hal ini telah menjadi isu yang berkepanjangan, dimana beberapa penulis menyatakan bahwa manajemen dan sistem pelaporan yang telah mapan selama ini secara berkelanjutan kehilangan relevansinya karena tidak mampu menyajikan informasi yang esensial bagi eksekutif untuk mengelola proses yang berbasis pengetahuan (knowledge-based processes) dan intangible resources (Bornemann dan Leitner, 2002).

Implementasi IC (Intellectual Capital) merupakan sesuatu yang masih baru, bukan saja di Indonesia tetapi juga di lingkungan bisnis global. Pada umumnya kalangan bisnis masih belum menemukan jawaban yang tepat mengenai nilai lebih apa yang dimiliki perusahaan. Nilai lebih ini sendiri dapat berasal dari kemampuan berproduksi suatu perusahaan sampai pada loyalitas pelanggan terhadap perusahaan. Nilai lebih ini dihasilkan oleh IC (Intellectual Capital) yang dapat diperoleh dari budaya pengembangan perusahaan maupun kemampuan perusahaan dalam memotivasi karyawannya sehingga produktivitas perusahaan dapat dipertahankan atau bahkan dapat meningkat.

Akuntansi dengan produk utamanya pelaporan keuangan telah lama dirasakan manfaatnya sebagai salah satu sarana untuk mengambil keputusan yang bermanfaat. Disadari oleh para pemakai pelaporan keuangan bahwa informasi yang disajikan memiliki berbagai keterbatasan yang melekat didalamnya seperti sifatnya yang umum, kuantitatif, historis, dinyatakan dalam unit uang, serta sarat akan taksiran (Statement Accounting Concept No. 1). Meskipun memiliki banyak keterbatasan, penggunaan pelaporan keuangan untuk berbagai kepentingan baik bagi pihak internal maupun pihak eksternal perusahaan selama ini tetap diperlukan. Tetapi penyempurnaan dan kelengkapan informasi yang disajikan harus terusmenerus ditingkatkan dan disesuaikan dengan kebutuhan pengguna. Disadari pula bahwa pengguna eksternal utama pelaporan keuangan adalah para investor atau calon investor maka informasi yang memenuhi kebutuhan mereka untuk pengambilan keputusan sudah selayaknya mendapat perhatian.

Di Indonesia, IC (Intellectual Capital) muncul sejak diterbitkannya PSAK No 19 (revisi 2009) tentang aktiva tidak berwujud. Namun, tidak dinyatakan secara langsung sebagai IC (Intellectual Capital). Menurut PSAK No 19, aktiva tidak berwujud adalah nilai spesifik entitas adalah nilai sekarang dari arus kas entitas yang diharapkan timbul dari meneruskan menggunakan aset dan dari pertukaran aset tersebut pada akhir masa manfaatnya atau diharapkan muncul saat menetapkan kewajiban. Beberapa contoh dari aktiva tidak berwujud telah disebutkan dalam PSAK No. 19 (revisi 2009) antara lain ilmu pengetahuan dan teknologi, desain dan implementasi sistem atau proses baru, lisensi, hak kekayaan intelektual, pengetahuan mengenai pasar dan merek dagang (termasuk merek produk/brand names). Selain itu juga disebutkan piranti lunak komputer, hak paten, hak cipta, film gambar hidup, daftar pelanggan, hak penguasaan hutan, kuota impor, waralaba, hubungan dengan pemasok atau pelanggan, kesetiaan pelanggan, hak pemasaran, dan pangsa pasar. PSAK No. 19 (revisi 2009) telah menyinggung mengenai IC (Intellectual Capital) walaupun tidak secara langsung. Hal ini menunjukkan bahwa IC (Intellectual Capital) telah mendapat perhatian. Akan tetapi, dalam praktiknya perusahaan - perusahaan di Indonesia belum memberikan perhatian yang lebih terhadap ketiga komponen IC (Intellectual Capital). perusahaan-perusahaan di Indonesia cenderung menggunakan

p.ISSN: $2407-800 X \quad$ e.ISSN: 2541-4356 
conventional based dalam membangun bisnisnya sehingga produk yang dihasilkan masih miskin kandungan teknologi. Padahal agar dapat bersaing dalam era knowledge based business, ketiga komponen IC (Intellectual Capital) tersebut diperlukan untuk menciptakan value added bagi perusahaan. Penciptaan nilai (value creation) dapat digunakan sebagai indikator pertumbuhan dan keberhasilan bisnis .Penciptaan nilai bagi perusahaan adalah ketika perusahaan mampu menghasilkan sesuatu yang lebih dari sumber daya yang diinvestasikan.

Dengan kata lain, apabila perusahaan mampu mengelola dan memanfaatkan sumber daya yang dimiliki sehingga sumber daya tersebut dapat menciptakan value added bagi perusahaan, maka hal ini disebut sebagai value creation. Penciptaan nilai yang tidak berwujud (intangible value creation) harus mendapatkan perhatian yang cukup karena hal ini memiliki dampak yang sangat besar terhadap kinerja perusahaan. dan dalam value creation, format yang terukur/berwujud (tangible form) seperti pendapatan tergantung pada format yang tidak berwujud (intangible form). Hal ini dapat dicontohkan, apabila perusahaan bertujuan untuk meningkatkan penciptaan laba, maka diperlukan pelayanan dan hubungan yang baik dengan pelanggan. Pelayanan yang baik akan memuaskan pelanggan sehingga terwujud pelanggan yang setia. IC (Intellectual Capital) merupakan sumber daya yang unik sehingga tidak semua perusahaan dapat menirunya. Hal inilah yang menjadikan IC (Intellectual Capital) sebagai sumber daya kunci bagi perusahaan untuk menciptakan value added perusahaan dan nantinya akan tercapai keunggulan kompetitif perusahaan. Perusahaan yang memiliki keunggulan kompetitif tentunya akan mampu bersaing dan bertahan di lingkungan bisnis.

Saat ini, IC (Intellectual Capital )telah menjadi aset yang sangat bernilai dalam dunia bisnis modern,karena IC (Intellectual Capital ) merupakan bagian dari diri manusia, struktural, dan manifestasi pelanggan yang dapat mendukung suatu pekerjaan dengan kuat. Berdasarkan teorinya, ekonomi informasi mempunyai konsekuensi yang sangat praktis dan besar bagi manajemen dan karir. Suatu perusahaan harus menemukan suatu cara yang baru di dalam beroperasi di tengah-tengah bisnis dan ekonomi yang baru ini. Hal ini diperlukan agar perusahaan dapat membuat keputusan yang bijak dan tepat tentang bagaimana cara survive di dalam persaingan

Hal ini menimbulkan tantangan bagi para akuntan untuk mengidentifikasi, mengukur dan mengungkapkannya dalam laporan keuangan. Akuntansi tradisional yang digunakan sebagai dasar pembuatan laporan keuangan dirasa gagal dalam memberikan informasi mengenai IC (Intellectual Capital). Dilain pihak, para pengguna laporan keuangan membutuhkan informasi kuantifatif dan kualitatif sebagai evaluasi kinerja perusahaan serta informasi mengenai IC (Intellectual Capital) yang dimiliki perusahaan. Praktik akuntansi tradisional hanya mampu mengakui intellectual property sebagai aset tak berwujud dalam laporan keuangannya, seperti paten, merk dagang dan goodwill (Starovic et.al, 2003). Intangible baru seperti kompetensi staf, hubungan pelanggan, model simulasi, sistem komputer dan administrasi tidak memperoleh pengakuan dalam model keuangan tradisional.

Ulum (2008) meneliti hubungan antara IC (Intellectual Capital) dengan kinerja perusahaan perusahaan perbankan yang terdaftar di BEI selama tahun 20042006. Hasil penelitian didapat bahwa terdapat pengaruh IC (Intellectual Capital) (VAIC) terhadap kinerja keuangan perusahaan. IC (Intellectual Capital) juga berpengaruh terhadap kinerja keuangan masa depan. Hasil yang lain adalah tidak ada pengaruh ROGIC (rate of growth of intellectual capital) terhadap kinerja keuangan perusahaan masa depan.

$$
\text { p.ISSN: } 2407-800 X \quad \text { e.ISSN: 2541-4356 }
$$


Penelitian ini merupakan replikasi dari penelitian yang dilakukan oleh Bontis (2000) dan Pulic (2000) . Perbedaan penelitian ini terletak pada perusahaan yang yang terdaftar diBursa Efek Indonesia yang akan dilihat pada 4 (empat) sektor industri, yaitu sektor manufaktur, jasa, perdagangan dan property. Data yang dianalisis pada penelitian ini adalah annual report perusahaan pada tahun 2007-2009. Pada tahun terakhir ini beberapa perusahaan sangat memperhatikan IC (Intellectual Capital) sebagai upaya untuk meningkatkan value perusahaan. Dan penelitian ini dilakukan di Bursa Efek Indonesia (BEI) karena sejauh ini, penelitan yang menghubungkan IC (Intellectual Capital) terhadap nilai pasar perusahaan belum banyak ditemukan di Indonesia.

Barney, 1986 dalam Madhani, 2009, mengemukakan pendapatnya mengenai Resources Based Theory dimana sumber daya yang dimiliki perusahaan dan bagaimana perusahaan tersebut dapat mengolah dan memanfaatkan sumber daya yang dimilikinya. Kemampuan perusahaan dalam mengelola sumber dayanya dengan baik dapat menciptakan keunggulan kompetitif sehingga dapat menciptakan nilai bagi perusahaan. Sedangkan Menurut Susanto (2007), agar dapat bersaing organisasi membutuhkan dua hal utama. Pertama, memiliki keunggulan dalam sumber daya yang dimilikinya, baik berupa aset yang berwujud (tangible assets) maupun yang tidak berwujud (intangible assets). Kedua, adalah kemampuan dalam mengelola sumber daya yang dimilikinya tersebut secara efektif. Kombinasi dari aset dan kemampuan akan menciptakan kompetensi yang khas dari sebuah perusahaan, sehingga mampu memiliki keunggulan kompetitif di banding para pesaingnya.

Dalam menentukan sumber daya kunci Resources Based Theory memberikan beberapa kriteria, yaitu :

a. Sumber daya tersebut mampu mendukung kemampuan perusahaan dalam memenuhi kebutuhan pelanggan yang lebih baik dibandingkan dengan perusahaan pesaing.

b. Sumber daya tersebut tersedia dalam jumlah terbatas atau langka dan tidak mudah ditiru. Terdapat empat karakteristik yang mengakibatkan sumber daya menjadi sulit ditiru, yaitu sumber daya tersebut unik secara fisik, memerlukan waktu yang lama dan biaya yang besar untuk memperolehnya, sumber daya unik yang sulit dimiliki dan dimanfaatkan pesaing, dan sumber daya yang memerlukan investasi modal yang besar untuk mendapatkannya.

c. Sumber daya tersebut dapat memberikan keuntungan bagi perusahaan. Semakin banyak keuntungan yang menjadi milik perusahaan akibat pemanfaatan sumber daya tertentu, maka semakin berharga sumber daya tersebut.

d. Durability (daya tahan sumber daya), semakin lambat suatu sumber daya mengalami depresiasi, semakin berharga sumber daya tersebut. Apalagi bila sumber daya yang dapat mengalami apresiasi, seperti brand awareness reputasi, dan budaya perusahaan.

IC (Intellectual Capital) memiliki peran yang sangat penting dan strategis di perusahaan, hal ini berawal ketika Tom Stewart, juni 1991, menulis sebuah artikel yang berjudul Brain Power- How Intellectual Capital Is Becoming America's Most Valuabel Asset, yang mengantar IC (Intellectual Capital) kepada agenda manajemen (Ulum, 2009). Dalam artikelnya, Stewart mendefinisikan IC (Intellectual Capital).

Definisi Intellectual Capital telah banyak diungkapkan oleh beberapa peneliti. Klein dan Prusak (dalam Ulum, 2009) memberikan definisi awal tentang IC (Intellectual Capital) . Menurut Klein dan Prusak IC (Intellectual Capital) adalah 
"material yang disusun, ditangkap, dan digunakan untuk menghasilkan nilai asset yang lebih tinggi".

Sementara itu Leif Edvinsson seperti yang dikutip oleh Brinker (2000:np) menyamakan IC sebagai jumlah dari human capital, dan structural capital (misalnya, hubungan dengan konsumen, jaringan teknologi informasi dan manajemen). The Society of Management Accountants of Canada (SMAC) mendefinisikan intellectual assets sebagai berikut: In balance sheet are those knowledge- based items, which the company owns which will produced a future stream of benefits for the company (IFAC, 1998 dalam Sawarjuwono, 2003).

Sedangkan menurut Zuhal : (2010) dalam Knowladge and Innovation : Platform kekuatan daya saing, mengemukakan bahwa intellectual capital adalah suatu asset pengetahuan yang kelak memungkinkan akan dapat meningkatkan nilai tambah menjadi sesuatu yang lebih berharga. Asset pengetahuan berupa talenta, keterampilan, teknologi know-how dan know what.

Sedangkan menurut Brooking (1997) dalam Agustina (2007) menyatakan bahwa sesuatu disebut IC (Intellectual Capital) jika memenuhi karakteristik sebagai berikut:

1. Aset yang memberikan perusahaan kekuatan dalam pasar (trademark, kesetiaan pelanggan, bisnis yang terus berulang.

2. Aset yang menyajikan property dari hasil pemikiran - intellectual property seperti paten, merk dagang, hak cipta.

3. Aset yang memberikan organisasi kekuatan internal, seperti budaya perusahaan, manajemen dan proses bisnis, kekuatan yang dihasilkan dari sistem teknologi informasi.

4. Aset yang dihasilkan dari individu yang bekerja di perusahaan seperti pengetahuan mereka kompetensi, kemampuan networking.

Empat langkah mengatur Intellectual menurut Thomas A.Stewart (2001) dalam Zuhal (2010) dalam perusahaan :
1. Merumuskan dan mengevaluasi peran ilmu pengetahuan dalam bisnis

a. Penekanan iptek mana yang akan menjadi fokus

b. Siapa yang akan dibayar dalam keahlian

c. Adakah yang akan mempunyai keahlian yang serupa dan dapat menghasilkan nilai tambah yang lebih baik

2. Cocokkan hasil yang diperoleh dengan aset pengetahuan yang dihasilkan

a. Tentukan keahlian, brand, hakcipta, proses dan modal intelektual lainnya yang akan meningkatkan nilai tambah bagi perusahaan

b. Cari kombinasi asset human capital, struktural capital dan costumer capital yang paling tepat

3. Kembangkan strategi untuk investasi dan memanfaatkan asset intelektual

a. Apa sumber dan model profit yang diinginkan

b. Strategi apa unuk meningkatkan intensitas pengetahuan pada bisnis

c. Mungkinkah akan memperoleh hasil yang lebih baik dengan cara merstrukturisasikan asset intelektual

4. Perbaiki efesiensi para pekerja ahli (knowladge worker)

a. Memberi dorongan akan produktivitas yang harus lebih ditingkatkan

IC (Intellectual Capital) dapat dilihat sebagai perpaduan antara human capital, structural capital dan customer capital. Menurut Bontis (1999) dalam Chen, et.al (2005), "A firm's intellectual capital, in broad sense, is comprised of human capital and structural capital" 
IFAC (1998) mengklasifikasikan IC (Intellectual Capital) dalam tiga kategori, yaitu: organizational capital, relational capital, dan human capital. Organizational capital meliputi intellectual property dan infrastructure assets.

\section{METODE}

Penelitian ini adalah penelitian eksploratif, yaitu penelitian yang dilakukan dengan maksud menggali secara luas tentang sebab akibat atau hal-hal yang mempengaruhi penelitian. Populasi penelitian ini adalah perusahan publik yang listing di Bursa Efek Indonesia (BEI). Sampel diperoleh dengan metode purposive sampling, yaitu kriteria yang sesuai dengan tujuan penelitian ini. Adapun kriteria-kriteria untuk menentukan sampel dalam penelitian ini adalah sebagai berikut :

1. Perusahaan yang terdaftar di Bursa Efek Indonesia pada tahun 20072009.

2. Perusahaan harus mempunyai laporan keuangan yang berakhir tanggal 31 Desember

3. Perusahaan jasa, property, manufaktur dan perdagangan.

4. Dalam laporan keuangan yang disajikan tidak memiliki saldo total ekuitas yang negatif dan atau mengalami kerugian selama tahun 2007-2009.

5. Perusahaan memiliki data yang lengkap sesuai kebutuhan penelitian ini.

Berdasarkan kriteria tersebut sampel penelitian ini dapat dilihat pada Tabel 3.1 dari hasil penyeleksian sampel tersebut didapat 241 perusahaan, sejak tahun 2007 sampai tahun 2009, Jumlah perusahaan yang terdaftar dibursa efek indonesia berjumlah 452 . Dengan demikian asumsi besar $\mathrm{n}$ yang dikehendaki metode analisis data dengan SPSS, yaitu $n=241$, pada penilitian ini telah terpenuhi.

Dalam beberapa sektor industri jumlah perusahaannya relatif kecil, sehingga kemudian perusahaan-perusahaan tersebut dikelompokkan lagi menjadi empat jenis industri terkait untuk meningkatkan jumlah sampel. Kelompok industri yang diteliti dalam penelitian ini sebagai berikut:

1. Sektor manufaktur yaitu perusahaan-perusahaan yang bergerak di bidang produksi dan pengolahan barang yang terdiri dari beberapa sector yaitu basic industry and chemicals,miscellaneous industry dan consumer food

2. Sektor perdagangan yaitu perusahaan-perusahaan yang memiliki bisnis terutama di bidang retail, perdagangan dan holding companies

3. Sektor jasa yaitu perusahaanperusahaan yang berhubungan dengan jasa, transportasi, storage dan komunikasi

Sektor properti yaitu perusahaanperusahaan yang berhubungan dengan properti, konstruksi dan hotel.

Metode pengumpulan data dilakukan dengan cara :

1) Studi Pustaka, metode ini dilakukan dengan cara mengumpulkan data yang relevan dari buku-buku, jurnal, artikel, peraturan perundangundangan yang terkait dan bahanbahan lain yang dapat menunjang penelitian ini.

2) Metode dokumentasi, Metode dokumentasi dilakukan dengan cara mengumpulkan data dari berbagai literatur dan juga data dari laporan tahunan yang dipublikasikan oleh Bursa Efek Indonesia dari Tahun 2007 - 2009 . Data dalam penelitian ini diperoleh dari Indonesia Capital Market Directory (ICMD)

Metode analisis yang digunakan dalam penelitian ini adalah analisis regresi linier berganda.

\section{HASIL}

Variabel yang dianalisis pada penelitian ini adalah variabel intellectual capital (dengan indikator Value added intellectual coefesient), variabel Kinerja Keuangan (dengan indikator return on

p.ISSN: $2407-800 X \quad$ e.ISSN: 2541-4356 
asset) Sedangkan objek penelitian ini adalah perusahaan yang listed di BEI, yang dibagi menjadi 4 (empat) sektor industri yaitu : perusahaan jasa, perusahaan manufaktur, perusahaan perdagangan dan perusahaan property

Perusahaan yang dijadikan subjek penelitian ini adalah Manufaktur yang tercatat di BEI. Pertimbangan atas pemilihan Perusahaan Manufaktur sebagai subyek penelitian diantara berbagai perusahaan yang listing di BEI dikarenakan Perusahaan Manufaktur banyak menggunakan human sebagai tenaga kerjanya. Selain itu Perusahaan Manufaktur tidak hanya berhubungan dengan produk yang diberikan tapi juga kualitas jasa secara langsung. Pengaruh intellectual capital akan semakin jelas.

Nilai $t$ hitung untuk variabel structural capital efficiency (STVA) memiliki nilai signifikansi uji t lebih kecil dari $\alpha=0,05$ yaitu sebesar 0.941, maka disimpulkan untuk menolak hipotesis nol. Dengan demikian hipotesis penelitian ditolak, dengan kata lain peningkatan atau penurunan structural capital efficiency (STVA) secara parsial tidak berpengaruh terhadap kinerja keuangan, pada perusahaan yang terdaftar di BEI periode 2007 - 2009.

Tabel 1. Hasil Regresi Uji Statistik VACA,VAHU,STVA terhadap ROE

\begin{tabular}{|l|l|l|l|l|l|}
\hline & \multicolumn{2}{|l|}{$\begin{array}{l}\text { Unstandardized } \\
\text { Coefficients }\end{array}$} & $\begin{array}{l}\text { Standardized } \\
\text { Coefficients }\end{array}$ & & \\
\cline { 2 - 5 } & $\mathrm{B}$ & Std. Error & Beta & $\mathrm{t}$ & Sig. \\
\hline (Constant) & 0.108 & 0.428 & & 0.253 & .801 \\
\hline VACA & -.002 & 0.005 & -.042 & - & .689 \\
\hline VAHU & -.003 & 0.004 & -.078 & 0.736 & .464 \\
\hline STVA & .147 & 0.156 & .095 & 0.941 & .349 \\
\hline
\end{tabular}

Sumber : Data sekunder yang diolah, 2012

Pada tabel 2 dapat dilihat Uji ANOVA pada perusahaan jasa dan property dengan asumsi Apabila probabilitas < dari 0.05 maka $\mathrm{H} 3$ ditolak dan apabila > dari 0.05 maka H3 diterima. Hanya variabel VAHU yang probabilitas $0.008<0.05$, maka H3 ditolak sedangkan pada perusahaan manufaktur dan perdagangan pada tabel 4.27 dapat dilihat bahwa ketiga variabel VACA,VAHU,STVA $<0.05$

Tabel 2. : Uji ANOVA pada human capital, structural dan relation capital terhadap ROE pada perusahaan manufaktur Tahun 2007 sampai 2009

\begin{tabular}{|l|l|l|l|l|}
\hline Variabel & $\begin{array}{l}\text { Sum of } \\
\text { square }\end{array}$ & $\begin{array}{l}\text { Mean of } \\
\text { square }\end{array}$ & F & Signifikansi \\
\hline VACA & 5.261 & 0.071 & 11.941 & 0.000 \\
\hline VAHU & 2.773 & 0.028 & 27.727 & 0.000 \\
\hline STVA & 13.039 & 0.135 & 39.255 & 0.000 \\
\hline
\end{tabular}

Sumber : Data sekunder diolah, 2012

\section{PEMBAHASAN}

\section{Hasil Pengujian Secara Parsial - Uji t}

Hasil uji regresi berganda Nilai t hitung untuk variabel capital employed efficiency (VACA) memiliki nilai signifikansi uji $\mathrm{t}$ lebih besar dari $\alpha=0,05$ yaitu sebesar 0.475, maka disimpulkan hipotesis nol gagal ditolak. Dengan demikian hipotesis penelitian ditolak, dengan kata lain peningkatan atau penurunan capital employed efficiency (VACA) secara parsial tidak berpengaruh terhadap Kinerja Keuangan pada perusahaan yang terdaftar di Bursa Efek Indonesia periode 2007 2009

Nilai t hitung untuk variabel human capital efficiency (VAHU) memiliki nilai signifikansi uji t lebih kecil dari $\alpha=0,05$ yaitu sebesar 0.719, disimpulkan untuk menolak hipotesis nol. Dengan demikian hipotesis penelitian ditolak, dengan kata lain peningkatan atau penurunan human capital efficiency (VAHU) secara parsial tidak berpengaruh terhadap kinerja keuangan pada perusahaan yang terdaftar di BEI periode 2007 - 2009.

Nilai $t$ hitung untuk variabel structural capital efficiency (STVA) memiliki nilai signifikansi uji t lebih kecil dari $\alpha=0,05$ yaitu sebesar 0.021, maka disimpulkan untuk menerima hipotesis nol. Dengan demikian hipotesis penelitian diterima, dengan kata lain peningkatan atau penurunan structural capital efficiency 
(STVA) secara parsial berpengaruh terhadap kinerja keuangan, pada perusahaan yang terdaftar di BEI periode 2007 - 2009.

Hal diterima apabila nilai $\mathrm{P}$ value $<\alpha$ diperoleh $\mathrm{P}$ value $<\alpha(0.05<0.05)$ berarti Ha1 diterima. Hasil penelitian menunjukkan bahwa Intellectual capital berpengaruh positif terhadap Return On Asset. Hasil ini sesuai dengan prediksi hipotesis pertama, berarti perusahaan public yang ada dibursa efek Indonesia mempertimbangkan Intellectual capital dalam menetapkan Return On Asset

Berdasarkan hasil uji $t$ yang dilakukan pada variabel VACA (X1), VAHU(X2), dan STVA(X3) dapat diambil kesimpulan bahwa ketiga variable indikator pembentuk intellectual capital berpengaruh signifikan secara parsial terhadap financial performance dengan indikator ROA. Selain secara parsial berpengaruh signifikan, secara simultan pun melalui uji $\mathrm{F}$ dapat diambil kesimpulan bahwa intellectual capital mempunyai pengaruh terhadap financial performance dengan indikator ROA dimana tingkat signifikansi lebih kecil dari $\alpha=0,05$ yaitu sebesar 0,050 .

Secara keseluruhan penelitian ini membuktikan bahwa intellectual capital berpengaruh besar terhadap Return On Assets perusahaan. Hal ini dapat dilihat pada Tabel R square sebesar $92.9 \%$. Ini apat diartikan bahwa intellectual capital mempengaruhi ROA perusahaan sebesar 92.9 $\%$ dan sisanya dipengaruhi oleh faktor lain yang tidak diteliti.

Hasil penelitian ini konsisten dengan hasil penelitian pulic (2000) dan bontis (2000) yang menemukan bahwa intellectual capital berpengaruh signifikan terhadap financial performance dengan indikator ROA. Semakin tinggi kenaikan intellectual capital akan meningkatkan nilai ROA Perusahaan. Ini mengindikasikan bahwa semakin mampu perusahaan mengolah intellectual capitalnya akan memberikan nilai tambah bagi perusahaan. Selain itu juga dapat dilihat bahwa efisiensi yang dilakukan terhadap ketiga modal perusahaan sangat berkontribusi terhadap keseluruhan peningkatan kinerja perusahaan

Hal serupa penenelitian ini sependapat dengan penelitian Chen et.al (2005) bahwa Intellectual capital berpengaruh signifikan terhadap Kinerja Keuangan (Financial Performance) dan Nilai Pasar Perusahaan (Market Value).

Hal ini bertolak belakang pada penelitian Margaretha dan Rakhman (2006) bahwa nilai pasar terdapat hubungan negatif secara signifikan antara Intellectual Capital dan Price Book Value (PBV). Terdapat hubungan positif antara ketiga komponen Intellectual Capital dan ROE sebagai kinerja keuangan. Perbedaan hasil penelitian ini dengan penelitian sebelumnya, dapat dikarenakan perbedaan pasar modal yang diteliti sehingga menyebabkan perbedaan penerapan efisiensi.

\section{Pengaruh Intellectual Capital (IC) yang terdiri dari Human Capital, Struktural Capital dan Relation Capital terhadap Return On Equity (ROE)}

Nilai t hitung untuk variabel capital employed efficiency (VACA) memiliki nilai signifikansi uji t lebih besar dari $\alpha=0,05$ yaitu sebesar -0.401, maka disimpulkan hipotesis ditolak. Dengan demikian hipotesis penelitian diterima, dengan kata lain peningkatan atau penurunan capital employed efficiency (VACA) secara parsial berpengaruh terhadap Kinerja Keuangan pada perusahaan yang terdaftar di Bursa Efek Indonesia periode 2007 - 2009

Nilai t hitung untuk variabel human capital efficiency (VAHU) memiliki nilai signifikansi uji t lebih kecil dari $\alpha=0,05$ yaitu sebesar 0.736, disimpulkan untuk menolak hipotesis nol. Dengan demikian hipotesis penelitian ditolak, dengan kata lain peningkatan atau penurunan human capital efficiency (VAHU) secara parsial tidak berpengaruh terhadap kinerja keuangan pada perusahaan yang terdaftar di BEI periode $2007-2009$.

Nilai $\mathrm{t}$ hitung untuk variabel structural capital efficiency (STVA) memiliki nilai signifikansi uji t lebih kecil 
dari $\alpha=0,05$ yaitu sebesar 0.941, maka disimpulkan untuk menolak hipotesis nol. Dengan demikian hipotesis penelitian ditolak, dengan kata lain peningkatan atau penurunan structural capital efficiency (STVA) secara parsial tidak berpengaruh terhadap kinerja keuangan, pada perusahaan yang terdaftar di BEI periode 2007 - 2009.

Dengan menggunakan uji $t$ dapat diketahui bahwa secara parsial STVA dan VAHU tidak berpengaruh signifikan terhadap financial performance dengan indikator ROE. Sedangkan VACA sebagai variabel independent pertama berpengaruh signifikan terhadap financial performance dengan indikator ROE. Walaupun secara parsial indikator intellectual capital tersebut tidak secara keseluruhan mempengaruhi ROE, namun secara simultan berpengaruh signifikan dengan tingkat signifikansi lebih kecil dari $\alpha=0,05$ yaitu 0,04 pada perusahaan dalam sektor jasa dan property .sedangkan rata-rata signifikansi pada perusahaan sektor manufaktur dan perdagangan sebesar 0.021 Namun proporsi pengaruhnya tidak terlalu besar jika dilihat pada tabel 4.12 , $\mathrm{R}$ square hanya menunjukkan nilai sebesar $53.2 \%$ pada tahun 2009 yang dapat diartikan bahwa intellectual capital mempengaruhi ROE hanya sebesar $53.2 \%$ dan sisanya dipengaruhi faktor lain yang tidak diteliti.

Hasil penelitian yang secara parsial tidak konsisten dengan penelitian Bontis dan Pulic (2000) yang menyatakan bahwa ketiga indikator intellectual capital berpengaruh signifikan terhdap ROE. Ketidak konsistenan antara lain disebabkan dari perbedaan pasar modal seperti yang telah dijelaskan di atas, penerapan pasar modal juga memberikan perbedaan penerapan pada intellectual capital yang menyebabkan perbedaan dalam membentuk penilaian pasar dan kinerja keuangan perusahaan.

Uji ANOVA pada perusahaan jasa dan property dengan asumsi Apabila probabilitas < dari 0.05 maka $\mathrm{H} 3$ ditolak dan apabila > dari 0.05 maka $\mathrm{H} 3$ diterima. Hanya variabel VAHU yang probabilitas $0.008<$ 0.05, maka H3 ditolak sedangkan pada perusahaan manufaktur dan perdagangan pada tabel 4.27 dapat dilihat bahwa ketiga variabel VACA,VAHU,STVA $<0.05$ artinya kinerja Intellectual capital pada perusahaan tersebut berbeda pada setiap industri, hal ini terjadi dikarenakan jumlah ekuitas yang diperoleh perusahaan pada sektor manufaktur dan perdagangan lebih besar dibandingkan perusahaan dalam sektor jasa dan property.

\section{SIMPULAN}

Berdasarkan pada hasil penelitian yang telah dilakukan maka dapat ditarik kesimpulan sebagai berikut : Capital employed efficiency (VACA) berpengaruh signifikan terhadap return on asset. Pengaruh yang diberikan VACA terhadap ROA adalah positif. Hal ini mengindikasikan bahwa efisiensi kinerja perusahaan jasa keuangan dalam menggunakan total assetnya dipengaruhi oleh efisiensi perusahaan dalam penciptaan aset dan pengelolaan sumber daya keuangannya Human capital efficiency (VAHU) berpengaruh signifikan terhadap return on assets. Pengaruh VAHU terhadap MB adalah positif. Hal ini mengindikasikan bahwa efisiensi kinerja perusahaan jasa keuangan dalam menggunakan total assetnya dipengaruhi oleh kemampuan perusahaan dalam mengolah sumber daya manusianya

Structural capital efficiency (STVA) tidak berpengaruh positif terhadap return on assets. Hal ini mengindikasikan bahwa efisiensi kinerja perusahaan dalam menggunakan total assetnya dilihat dari kemampuan perusahaan dalam memenuhi rutinitas perusahaan dan strukturnya yang mendukung usaha karyawan untuk tidak menghasilkan kinerja yang optimal.

Value added intellectual coefficiency (VAIC) yang terdiri dari komponen VACA, VAHU dan STVA secara bersama-sama (simultan) mempunyai pengaruh terhadap ROA. Ini mengindikasikan bahwa semakin mampu perusahaan mengolah intellectual capitalnya akan memberikan nilai tambah 
bagi perusahaan. Selain itu juga dapat dilihat bahwa efisiensi yang dilakukan terhadap ketiga modal perusahaan sangat berkontribusi terhadap keseluruhan peningkatan kinerja perusahaan.

Capital employed efficiency (VACA) tidak berpengaruh signifikan terhadap return on equity. Hal ini mengindikasikan bahwa tingkat pengembalian kepada pemilik atau stockholders perusahaan jasa keuangan tidak dipengaruhi oleh efisiensi perusahaan dalam penciptaan aset dan pengelolaan sumber daya keuangannya. Hal ini dikarenakan tingkat pengembalian kepada pemilik atau stockholders perusahaan jasa keuangan lebih didasarkan pada kemampuan perusahaan mengolah rutinitas yang menjadikan karyawan bekerja optimal.

Human capital efficiency (VAHU) tidak berpengaruh signifikan terhadap return on equity. Hal ini mengindikasikan bahwa tingkat pengembalian kepada pemilik atau stockholders perusahaan jasa keuangan tidak dipengaruhi oleh kemampuan perusahaan dalam mengolah sumber daya manusianya. Hal ini dikarenakan Hal ini dikarenakan tingkat pengembalian kepada pemilik atau stockholders

Structural capital efficiency (STVA) berpengaruh signifikan positif terhadap return on equity. Hal ini mengindikasikan bahwa tingkat pengembalian kepada pemilik atau stockholders perusahaan jasa keuangan dilihat dari kemampuan perusahaan dalam memenuhi rutinitas perusahaan dan strukturnya yang mendukung usaha karyawan untuk menghasilkan kinerja yang optimal.

1. Capital employed efficiency (VACA) tidak mempunyai pengaruh yang signifikan terhadap Price to Book Value perusahaan . Hal ini dimungkinkan karena dalam penilaian Price to Book Value perusahaan di BEI tidak didasarkan pada penciptaan asset atau pengelolaan sumber daya keuangannya, karena perusahaan jenis jasa terutama jasa keuangan lebih didasarkan pada pengelolaan sumber daya manusia dan struktur organisasinya

2. Human capital efficiency (VAHU) berpengaruh signifikan terhadap Price to Book Value perusahaan. Pengaruh VAHU terhadap Price to Book Value perusahaan berlawanan arah. Hal ini mengindikasikan bahwa penilaian Price to Book Value perusahaan di mata investor tidak dipengaruhi oleh kemampuan perusahaan dalam mengolah sumber daya manusianya. Hal ini dikarenakan perusahaan tidak pandai dalam mengelolapengeluaran yang dihasilkan untuk membiayai karyawannya, sehingga tidak menimbulkan nilai tambah bagi perusahaan.

3. Structural capital efficiency (STVA) berpengaruh signifikan positif terhadap Price to Book Value. Berbeda dengan VAHU, STVA berpengaruh positif terhadap Price to Book Value perusahaan. Hal ini mengindikasikan bahwa penilaian Price to Book Value dengan ukuran Intellectual Capital bergantung pada sebaik apa kemampuan perusahaan dalam memenuhi rutinitas perusahaan dan strukturnya yang mendukung usaha karyawan untuk menghasilkan kinerja yang optimal.

4. Value added intellectual coefficiency (VAIC) yang terdiri dari komponen VACA, VAHU dan STVA secara bersama-sama (simultan) mempunyai pengaruh terhadap Price to Book Value. Hal ini mengindikasikan bahwa, investor sudah menjadikan intellectual capital sebagai bahan pertimbangan dalam pengambilan keputusan investasi

5. Value added intellectual coefficiency (VAIC) yang terdiri dari komponen VACA, VAHU dan STVA secara bersama-sama (simultan) mempunyai pengaruh terhadap Tobin's $Q$ Ratio . Hal ini

p.ISSN: $2407-800 X \quad$ e.ISSN: 2541-4356 
mengindikasikan bahwa, investor sudah menjadikan intellectual capital sebagai bahan pertimbangan dalam pengambilan keputusan investasi

\section{DAFTAR RUJUKAN}

Agustina, Wulan. 2007. Analisis Pengaruh Intellectual Capital tehadap Kinerja Kantor Akuntan Publik di Surabaya.Fakultas Ekonomi Universitas Airlangga. Surabaya

Anonim. 2008. Indonesian Capital Market Directory 2008. Jakarta.

Bontis, 2001. Assesing knowledge assets : a review of the models used to measure intellectual capital.

Bontis, Nick. . National Intellectual Capital Index: A United Nations Initiative for Tha Arab Region. Journal of Intellectual Capital. Vol. 5 No. 1 pp: 13-39. Bradford.

Belkaoui, A. Riahi. 2003. Intellectual Capital and Firm Performance of US Multinational

Firms: A Study of the Resource-Based and Stakeholder Views. Journal of Intellectual Capital. Vol. 4 No.2, pp. 215-226. Bradford.

Between Intellectual Capital and Firms' Market Value and Financial Performance". Journal of Intellectual Capital, 6(2), 159-176.

Boekestein. Bram. 2006. The Relation Between Intellectual Capital and Intangible Assets of Pharmaceutical Companies. Journal of Intellectual Capital. Vol.7. Iss.2.

Chen, Ming-Chin, et. al. 2005. An Empirical Investigation of Relationship Between Intellectual Capital and Firm's Market Value and Financial
Performance.Journal of Intellectual Capital. Vol. 6 No. 2, pp. 159-176. Bradford.Availableonline:

Firer, S., \& Williams, S. M. 2003. "Intellectual Capital and Traditional Measures of Corporate Performance". Journal of Intellectual Capital, 4(3), 348-360.

Ghozali, Imam. 2005. "Aplikasi Analisis Multivariate dengan program SPSS”. Badan penerbit UNDIP : Semarang.

Ghozali, Imam. 2009. "Aplikasi Analisis Multivariate dengan program SPSS ”. Badan penerbit UNDIP : Semarang.

Ghozali, I. dan A. Chariri. 2007. "Teori Akuntansi Edisi 3": Badan Penerbit Universitas Diponegoro. Semarang

Gujarati, N. Damodar. 2003. Basic Econometric. 4th. International Edition. Mc Graw Hill.

Habiburrachman, 2008, "Kajian tentang pentingnya Intellectual Capital dalam mendukung Peningkatan Kinerja Perusahaan". Jurnal Administrasi dan Bisnis

Helfert, Erich. A., 1997. "Teknik Analisis Keuangan". Erlangga : Jakarta.

Halim, Abdul. Mamduh M. Hanafi. 2005. "Analisis Laporan Keuangan". UPP AMP-YKPN.Yogyakarta.

Ikatan Akuntan Indonesia. 2007. "Standar Akuntansi Keuangan". Salemba Empat : Jakarta.

Indonesia Stock Exchange, www.idx.co.id

p.ISSN: $2407-800 X$

e.ISSN: $2541-4356$ 
Imaningati. 2007. "Pengaruh Intellectual Capital terhadap Kinerja Perusaahan Real Estate \& Properti yang Terdaftar di BEI Tahun 2002-2006". Thesis. Universitas Diponegoro. Semarang.

Kuryanto, Benny dan M. Syafruddin. 2008. "Pengaruh Modal Intelektual terhadap Kinerja Keuangan Perusahaan”. Proceeding SNA XI. Pontianak.

Najibullah, Syed. 2005. "An Empirical Investigation of The Relationship Between Intellectual Capital and Firms' Market Value and Financial Performance : in Context of Commercial Banks of Bangladesh".

Frans Mardi Hartanto. 2009. Paragdima baru manajemen Indonesia: menciptakan nilai dengan bertumpu pada kebijakan dan potensi insani”. Penerbit Mizan. Bandung

Pulic, A. 2000b. www.vaic.on-net

Ramadhan, I. Ibnu. 2009. "Pengaruh Intellectual Capital terhadap Kinerja Perusaahan Manufaktur yang Terdaftar di BEI Tahun 2002-2007". Skripsi. Tidak Dipublikasikan. Universitas Diponegoro. Semarang.

Reich, Roberth B. n.d."Relational Capital", Http://www.WashingtonSpeaker.co m. Diakses 19 Februari 2010.

Sangkala. 2007. Knowledge Management: PT Raja Garfindo Persda. Jakarta

Sawarjuwono, T. Kadir, P.A. 2005. "Intellectual Capital: Perlakuan, Pengukuran, dan Pelaporan (Sebuah Library Research)". Jurnal Akuntansi dan Keuangan. Vol. 5 No. 1. pp. 35-57.
Susanto, A.B., 2007. "Resource Based Versus Market Based". Eksekutif no.338. Mei. Hlm.. 24- 25.

Stewart, Thomas A. 1998. Modal Intelektual: Kekayaan Baru Organisasi. Jakarta: Penerbit PT Elex Media Komputindo

Tan, Hong Pew, et. al. Intellectual Capital And Financial Returns of Companies. Journal of Intellectual Capital. Vol. 8 No. 1, 2007. pp: 76-95.

Ulum, Ihyaul, Imam Ghozali \& Anis Chariri. 2008. "Intellectual Capital dan Kinerja Keuangan Perusahaan: Suatu Analisis dengan Pendekatan Partial Least Squares". Proceeding SNAXI. Pontianak.

Ulum, Ihyaul. 2009. "Intellectual Capital : Konsep dan Kajian Empiris".Graha Ilmu. Yogyakarta

Woodcock, J., H.R. Whiting. 2009. "Intellectual Capital Disclosure by Australian Companies". Paper accepted for presentation at the AFAANZ Conference, Adelaide, Australia. Juli 2009.

Zuhal. 2010. "Knowladge and Innovation : Platform Kekuatan Daya Saing". Gramedia Pustaka Utama. Jakarta. 